\title{
Geochemistry and Origin of the Hyper Salinity of Groundwater in Wasia-Biyadh Aquifer, Saudi Arabia
}

\author{
Muhammad Gomaah ${ }^{*}$, Abdulaziz Al-Bassam² \\ ${ }^{1}$ United Nations Developing Program (UNDP) \& Ministry of Environment, Water \& Agriculture, Riyadh, Saudi Arabia \\ ${ }^{2}$ National Center for Research and Water Studies, Ministry of Environment, Water \& Agriculture, Riyadh, Saudi Arabia \\ Email: *muhammad_gomaah@yahoo.com
}

How to cite this paper: Gomaah, M., \& Al-Bassam, A. (2021). Geochemistry and Origin of the Hyper Salinity of Groundwater in Wasia-Biyadh Aquifer, Saudi Arabia. Journal of Geoscience and Environment Protection, 9, 1-14.

https://doi.org/10.4236/gep.2021.911001

Received: October 6, 2021

Accepted: November 6, 2021

Published: November 9, 2021

Copyright $\odot 2021$ by author(s) and Scientific Research Publishing Inc. This work is licensed under the Creative Commons Attribution International License (CC BY 4.0).

http://creativecommons.org/licenses/by/4.0/

\section{(c) (i) Open Access}

\begin{abstract}
The origin of the hyper saline groundwater in aquifers all over the world is still unclear till today. The current paper is an attempt to interpret a possible origin of the hyper salinity in the groundwater of the Wasia-Biyadh Aquifer system in Saudi Arabia. The result indicated that the major factors contributing salinity to groundwater are silicate weathering and evaporite dissolution/and or evaporation, as indicated by the $\mathrm{Na}^{+}$-normalized $\mathrm{Ca}^{2+} \mathrm{VS} \mathrm{HCO}_{3}^{-}$ plot. However, some groundwater samples showed hyper salinity that had been attributed to the presence of a naturally-occurring-hydrothermal system, due to the high concentration of the radionuclides within the aquifer. The high-salinity samples ( $\mathrm{Na}-\mathrm{Cl}$ type) plot under the evaporation line on the $\mathrm{Na}^{+} / \mathrm{Cl}^{-}$vs. $\mathrm{Cl}^{-}$relationship, suggesting deep heating that resulted in hyper salinity. The geochemical reactions in the eastern part of the aquifer included the precipitation of pyrite, dolomite, clay, and the incongruent dissolution of plagioclase.
\end{abstract}

\section{Keywords}

Geochemistry, Hyper Salinity, Groundwater, Wasia-Biyadh Aquifer

\section{Introduction}

Salinity of groundwater is a function of many chemical and physical factors, such as the mineral composition, lithology of the aquifer, oxidation reduction reactions, natural or artificial recharge and discharge, weathering, exchange reactions (Elango \& Kannan, 2007). Groundwater is classified generally according to the total dissolved solids (TDS) concentration as fresh $(<1000 \mathrm{mg} / \mathrm{L})$, brackish 
(1000 - 10,000 mg/L), saline (10,000 - 100,000 mg/L), and briny water $(>100,000$ $\mathrm{mg} / \mathrm{L})$ (Freeze \& Cherry, 1979). Another classification based on chloride ion classifies groundwater into four categories as fresh $(<300 \mathrm{mg} / \mathrm{L})$, brackish (300 to $10,000 \mathrm{mg} / \mathrm{L})$, salt $(10,000$ to $20,000 \mathrm{mg} / \mathrm{L})$, and hypersaline $(>20,000 \mathrm{mg} / \mathrm{L})$ (Stuyfzand \& Stuurman, 1994). Engelen et al. (2018) considered groundwater with salinity $>35,000 \mathrm{mg} / \mathrm{L}$ as "hypersaline".

The origin of the hypersaline groundwater in aquifers all over the world is still unclear until today, yet several authors made attempts such as De Sitter (1947), White (1965), and Berry (1969). They introduced the so-called "salt-sieving", also known as "natural reverse osmosis" which stated that shale and clays are considered as semi-permeable membranes, and are capable of preventing ions during the compaction of seawater-saturated sediments. Such mechanism could be applied to groundwater leakages through aquitards. However, certain conditions must exist to produce such groundwater flow patterns.

Avrahamov et al., 2014 indicated that the microbial evidence pointed to the anaerobic oxidation of methane (AOM) along with the bacterial sulfate reduction in the hypersaline groundwater of the Dead Sea (DS) Aquifer. Engelen et al., 2018 referred the origin of the hypersaline groundwater in the Nile Delta Aquifer (NDA) to the leakage of hypersaline groundwater from deeper deposits, or to the evapotranspiration of seawater. Sabarathinam et al., 2020 referred the origin of hyper salinity in the acidic hypersaline coastal groundwater in Kuwait to the bacterial oxidation of organic matter and the oxidation-reduction cycles of Fe.

In the present paper, we are seeking to explain the origin of the hyper salinity in deep seated groundwater of Wasia-Biyadh Aquifer.

\section{Methods}

The Ministry of Environment Water and Agriculture (MEWA) conducted the current research in cooperation with the Deutsche Gesellschaft für Internationale Zusammenarbeit (GIZ) as an internal report project, titled "Detailed Groundwater Resources Studies in the Rub Al-Khali Desert. Additional data was compiled from MOWE (2013a, 2013b, 2013c), BRGM (1976), and Al-Mashaikhi (2011). A total of 31 groundwater samples were collected by the GIZ from November 2010 to December 2011 for major cations and anions, trace elements and radionuclides. All Groundwater samples were collected in $100 \mathrm{~m} \ell$ bottles, filtered using a $0.45 \mu \mathrm{m}$ filter and preserved in cooling boxes. Nitric acid $\left(\mathrm{HNO}_{3}\right.$ $70 \%$ ) has been added additionally to samples assigned for cation analysis. All field measurements involved EC, T, pH dissolved oxygen, hydrogen sulfide and bicarbonate using multi-parameter pocket meters and a flow-through-cell (WTW, Multi 340i). Groundwater samples were also collected for trace elements in 250 $\mathrm{ml}$ bottles, then shipped to the laboratory in Darmstadt Technical University, Germany. The following analytical techniques have been applied to identify the chemical composition of the water samples:

- Ion chromatography (IC; major ions)

- Atomic Absorption Spectrometry (AAS; $\mathrm{Fe}^{2+}$ ) 
- Photometric tests (B, $\mathrm{SiO}_{2}$ )

- Gravimetry (TDS)

- Atomic Absorption Spectrometry, ICP/MS, and ICP-OES (trace elements)

- Isotope Ratio Infrared Spectrometry (IRIS) was used to for the ${ }^{2} \mathrm{H}$ and ${ }^{18} \mathrm{O}$ analysis

\section{Hydrogeology}

The Biyadh and the overlying Wasia Aquifer are of lower to mid Cretaceous age, composed of medium to coarse grained sandstone of a non-marine origin with some interbedded shale (MEWA, 2017d). In the western part of the study area (Figure 1), close to the outcrop, the Biyadh and the overlying Wasia Aquifer are in direct contact, forming the Wasia-Biyadh aquifer, which is considered a principal aquifer in Saudi Arabia, whereas in the eastern part they are separated by Shuaiba aquitard (Figure 2). The sandstone dips laterally in the subsurface under Rub' Al Khali depression, grading into shaly facies that completely replaced by limestone and argillaceous limestone in the easten part of the study area (Kalbus et al., 2011). The Wasia-Biyad Aquifer system is unconformably topped with dolomite and limestone of the Aruma Formation as illustrated in the hydrogeologic cross section (Figure 2) which extends from west to east across Rub $\mathrm{Al}$ Khali area. Over most parts of the study area the Wasia-Biyadh aquifer is confined, while the unconfined conditions prevail only in the western part. The investigated area belongs commonly to an arid climate due to the low precipitation and high evaporation rate. The mean annual rainfall range between 100 $220 \mathrm{~mm} / \mathrm{y}$, and the temperature reaches more than $50^{\circ} \mathrm{C}$ in summers (Kalbus et al., 2011).

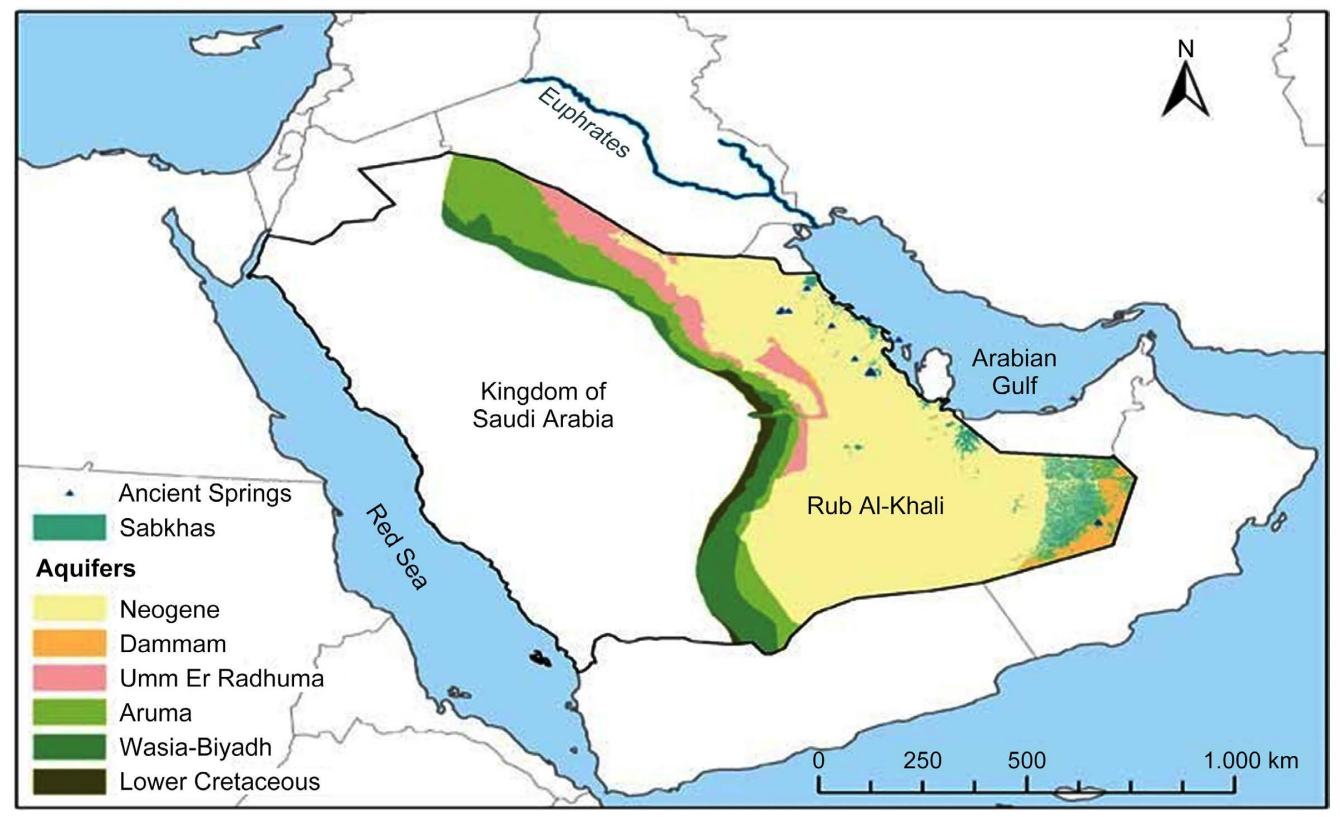

Figure 1. Location of the study area showing the extent and outcrop of the Wasia-Biyadh Aquifer (after Kalbus et al., 2011). 


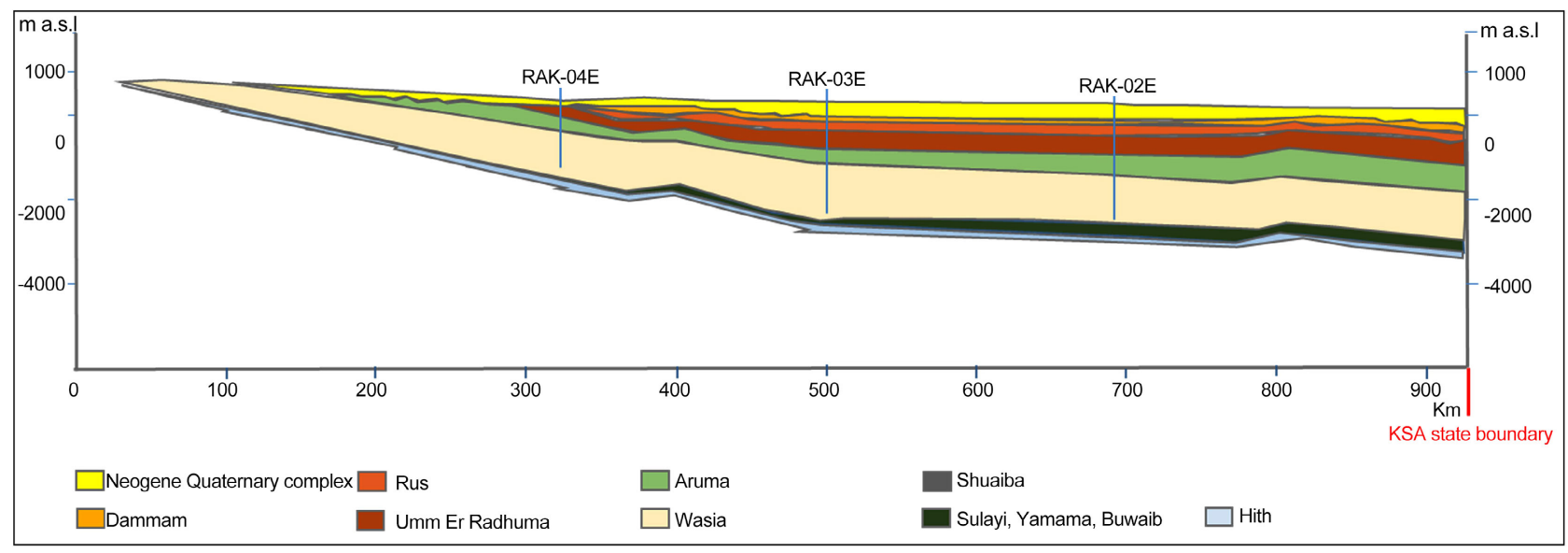

Figure 2. Hydrogeologic cross section for the investigated area from west to east.

\section{Results and Discussion}

\subsection{Major Geochemical Processes}

The groundwater samples in the western parts of the aquifer showed a broad range of TDS concentration, ranging between a few hundred to $3000 \mathrm{mg} / \ell$, belonging to a $\mathrm{Ca}-\mathrm{HCO}_{3}$ water type. A gradual increase in the ion concentrations was observed in groundwater along the flow path. However, some samples showed very high salinity with a TDS concentration of up to $230,000 \mathrm{mg} / \ell$ and a $\mathrm{Na}-\mathrm{Cl}$ water type towards the eastern parts of the study area (Figure 3). A $\mathrm{Na}^{+}$-normalized $\mathrm{Ca}^{2+}$ VS $\mathrm{HCO}_{3}^{-}$plot suggested by Gaillardet et al. (1999) was employed to identify the relative contributions of the major weathering/dissolution mechanisms (silicate, carbonate, and evaporite) to the ion concentrations in groundwater. Based on Figure 4, most of groundwater samples fell in the area of silicate weathering and evaporation/and or evaporite dissolutions, indicating that the major mechanisms which contribute ions and solutes are silicate mineral weathering and evaporite dissolution and/or evaporation.

\subsection{Water-Rock Interaction}

The main constituent of the sandstone in the western part of Wasia-Biyadh Aquifer is mainly Quartz (95\%) with minor percentage of K-feldspars (1\%) and clay (5\%) according to the XRD (Figure 5) which has been carried out by the GIZ. The main geochemical reaction in such part of the aquifer is the incongruent dissolution of K-feldspars which results in releasing potassium, bicarbonate and silica into groundwater as indicated by Equation (1).

$2 \mathrm{KAlSi}_{3} \mathrm{O}_{8}+2 \mathrm{H}_{2} \mathrm{CO}_{3}=2 \mathrm{~K}^{+}+\mathrm{Al}_{2} \mathrm{Si}_{2} \mathrm{O}_{5}(\mathrm{OH})_{4}($ kaolinite $)+2 \mathrm{HCO}_{3}+4 \mathrm{H}_{4} \mathrm{SiO}_{4}(1)$

In the eastern part of the aquifer, The XRD for a core sample (RAK-02E) indicated that quartz is the main constituent of the sandstone aquifer (Figure 6) in addition to minor percentages of plagioclase, dolomite, pyrite, and clay. The precipitation of pyrite in this portion of the aquifer was driven by the Sulfate-reducing bacteria (SRB). It can perform anaerobic respiration utilizing sulfate as a terminal 


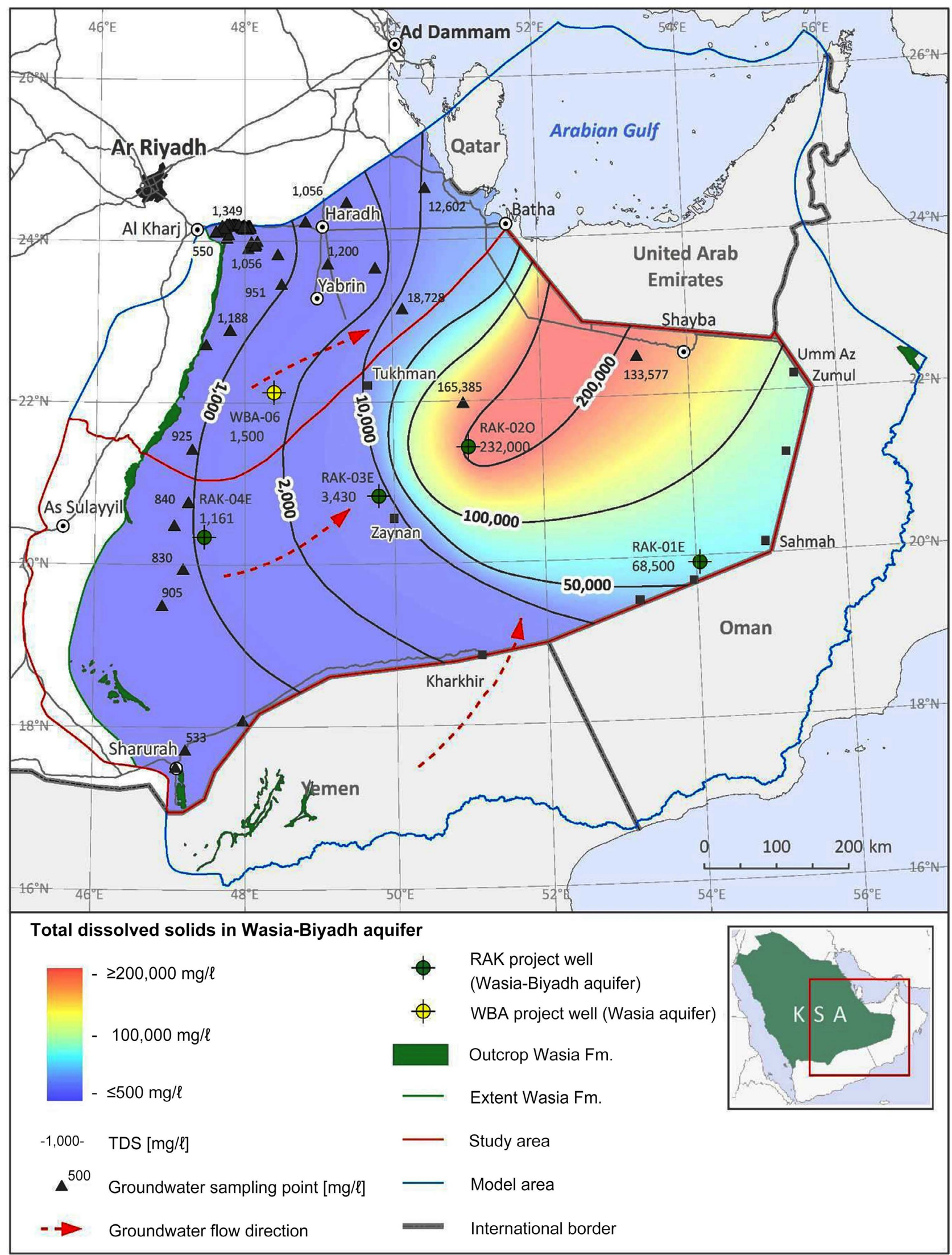

Figure 3. Total Dissolved Solids (TDS) distribution for Wasia-Biyadh aquifer (MEWA, 2017c). 


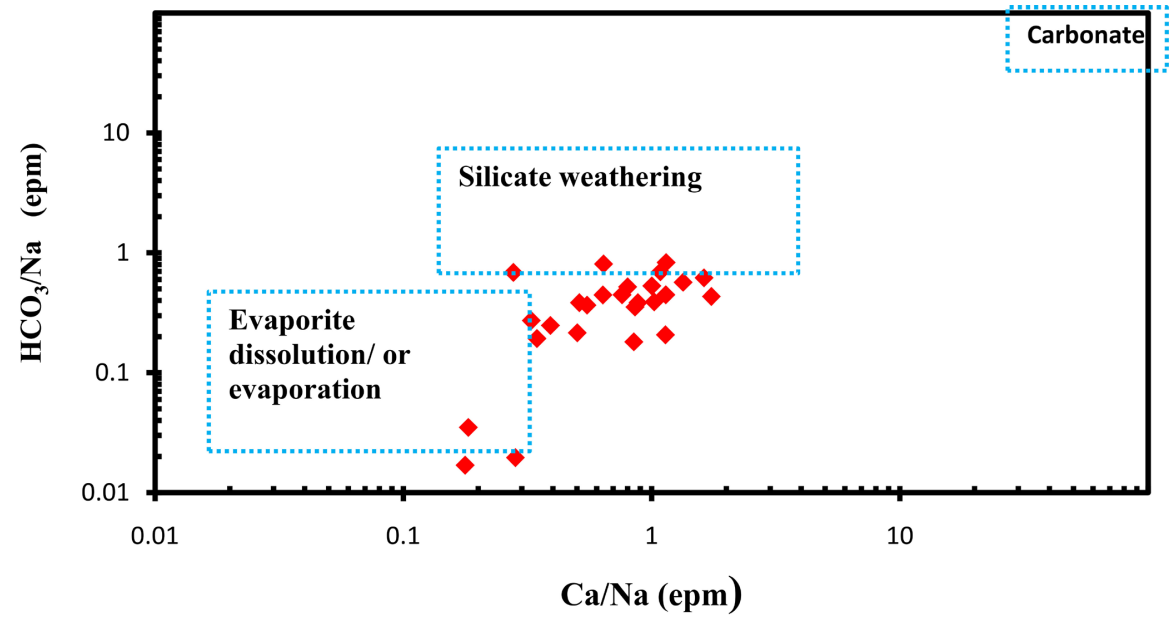

Figure 4. $\mathrm{Na}^{+}$-normalized $\mathrm{Ca}^{2+}$ VS $\mathrm{HCO}_{3}^{-}$plot, showing that silicate weathering and evaporite dissolution are the main sources of ions.

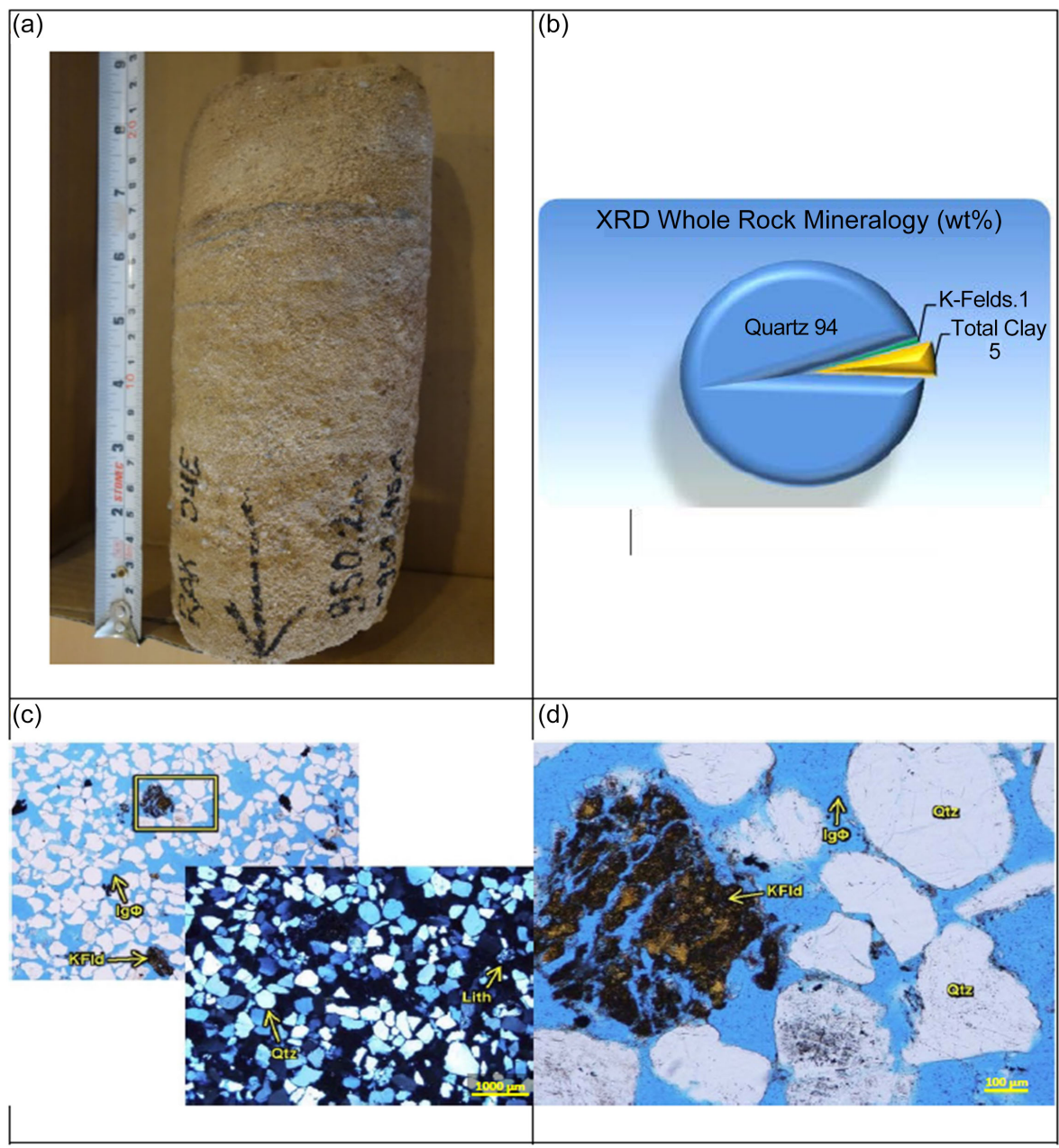

Figure 5. (a) Core sample RAK 04-E. (b) Pie chart showing the results from the X-Ray Diffraction (XRD) Analysis. (c) Low magnification view of PPL and XPL images showing abundant quartz (Qtz), minor K-feldspar, lithic fragment (Lith) and intergranular porosity $(\operatorname{Ig} \Phi)$. (d) High magnification view highlighting quartz (Qtz), and intergranular pores (Ig $\Phi)$ and the dissociated K-feldspar (KFld) (MEWA, 2017b). 


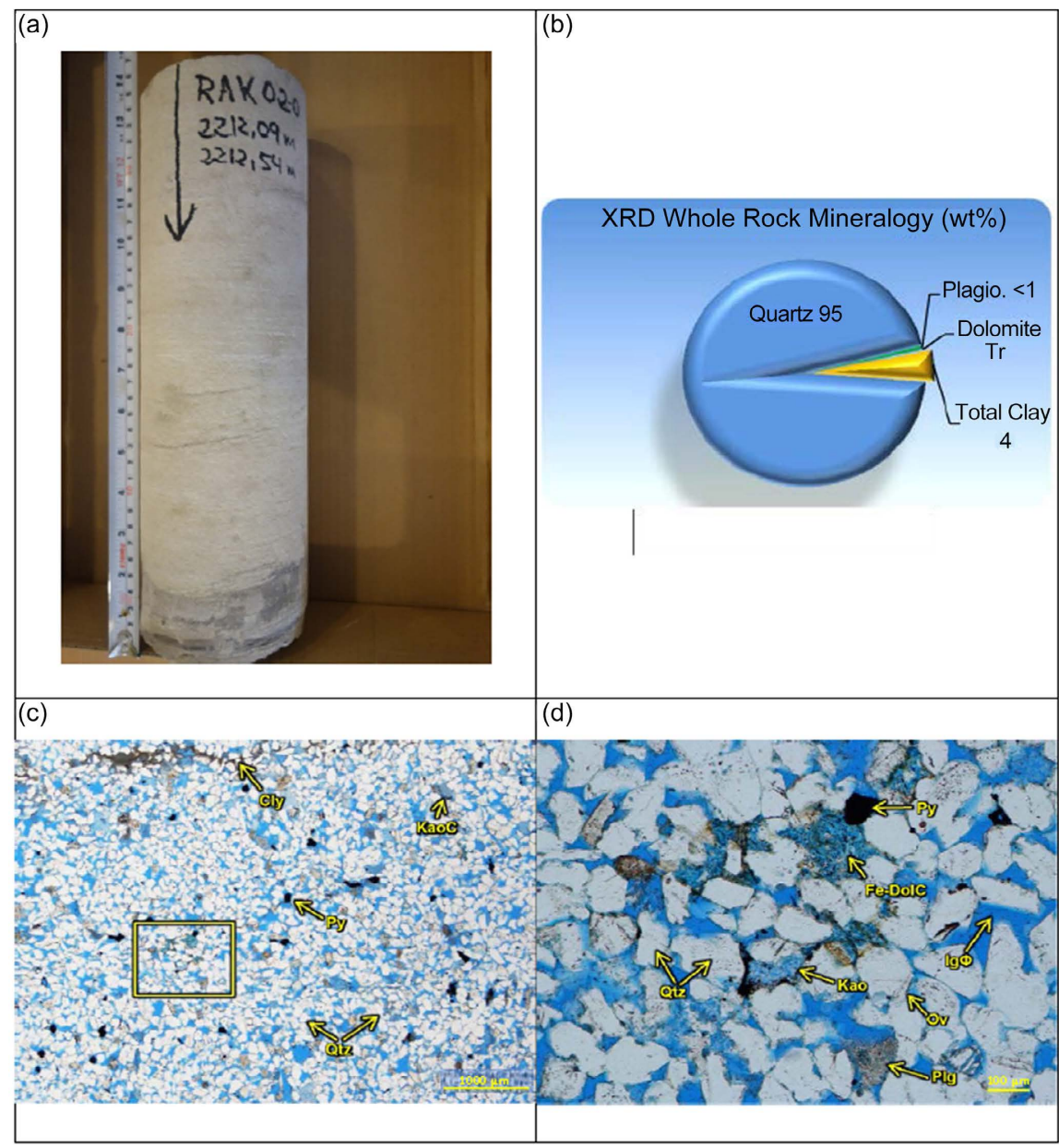

Figure 6. (a) Core sample of Wasia Aquifer at RAK 02-0 well. (b) Pie chart showing the result of XRD analysis. (c) Low magnifigation of wasia sandstone under the microscope. (d) High magnification of wasia sandstone under microscope showing Quartz (Qtz), trace plagioclase $(\mathrm{Plg})$, intergranular pore $(\mathrm{Ig} \Phi)$ cementing ferroan dolomite (Fe-DolC) and kaolinite (Kao) observed. Minor pyrite (Py) noted (MEWA, 2017b).

electron acceptor (Equation (2)), reducing it to sulfur or hydrogen sulfide. Based on Figure 7, sulfate concentration decreases from west to north east due to the reduction process. The produced sulfur reacts with $\mathrm{Fe}^{2+}$ to precipitate pyrite (Equation (3)). $\mathrm{Fe}^{2+}$ is produced in the groundwater by the reduction of $\mathrm{Fe}^{3+}$ (Equation (4)) and the precipitation of ferroan dolomite (iron dolomite) that was also driven by the anaerobic bacteria in the aquifer (Equation (5)).

$$
\begin{gathered}
\mathrm{SO}_{4}^{2-}+(\mathrm{SRB})=\mathrm{S} \\
\mathrm{S}+\mathrm{Fe}^{2+}=\mathrm{FeS}_{2} \\
\mathrm{Fe}^{3+}(\text { solid })+(\mathrm{SRB})=\mathrm{Fe}^{2+} \\
\mathrm{Ca}^{2+}+\mathrm{Mg}^{2+}+\mathrm{Fe}^{2+}+2 \mathrm{CO}_{3}^{-}=\mathrm{CaFeMg}\left(\mathrm{CO}_{3}\right)_{2}
\end{gathered}
$$

The incongruent dissociation of plagioclase, albite and anorthite introduced clays as secondary minerals to the aquifer in addition to sodium, calcium and silica to groundwater (Equations (6) \& (7)). This was confirmed by the stability 


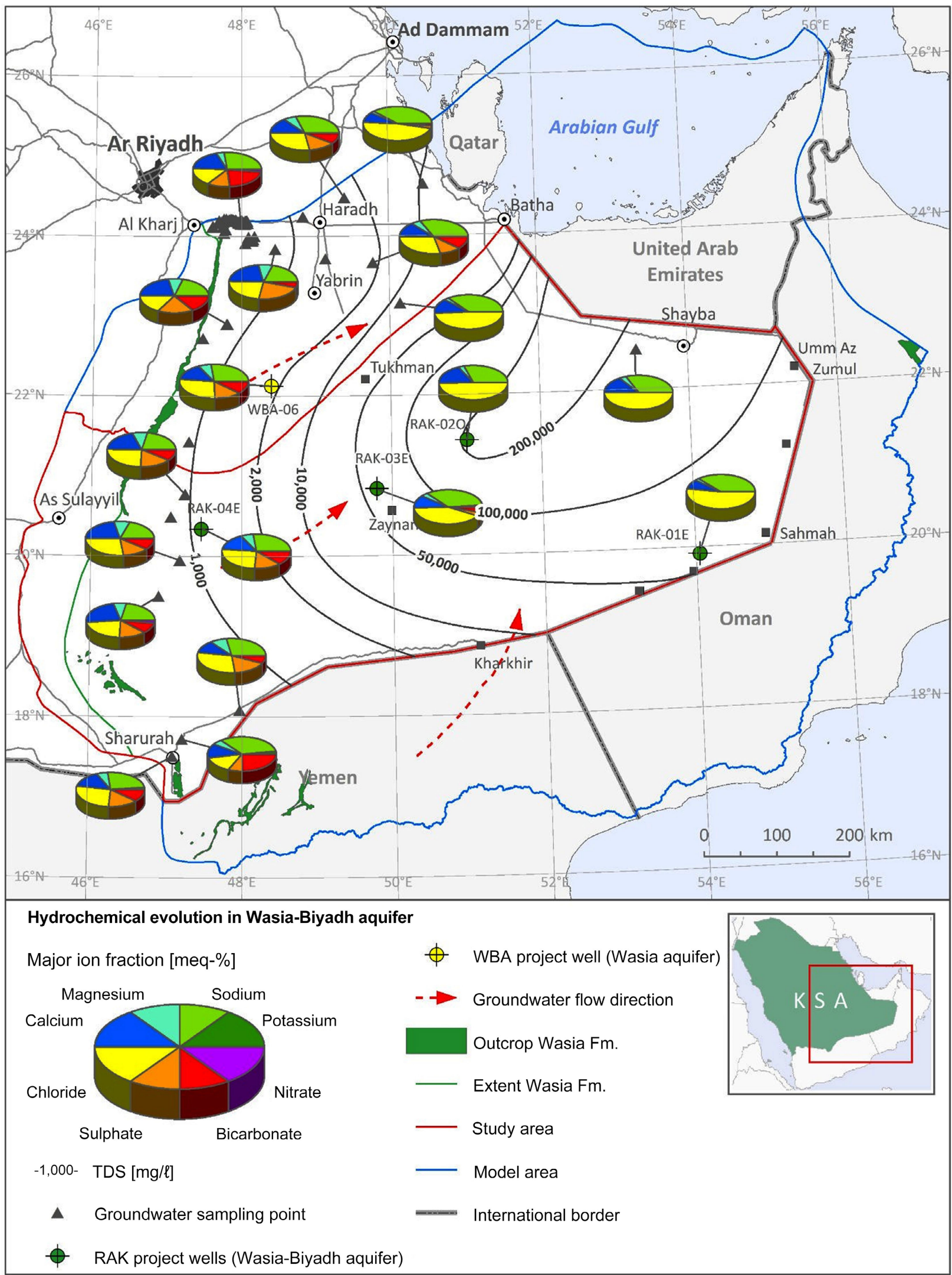

Figure 7. The hydrochemical distribution of ions within Wasia-Biyadh aquifer, sulfate concentration decreases from west to north east due to reduction. 
diagrams (Figure 8) for some groundwater samples that appeared to lie at/or close to equilibrium with kaolinite, illite, and montmorillonite. This also could be confirmed by applying the geochemical model phreeqc along the flow path in the eastern part of the aquifer to deduce the plausible reactions which account for solutes in the groundwater. The RAK-03E was selected as the initial well, and RAK-02E as the final. The result of the model is presented in Table 1.

$$
\begin{gathered}
\underset{\text { albite }}{2 \mathrm{NaAlSi}_{3} \mathrm{O}_{8}+9 \mathrm{H}_{2} \mathrm{O}+2 \mathrm{H}^{+}} \rightarrow \underset{\text { kaolinite }}{2 \mathrm{Na}^{+}+} \mathrm{Al}_{2} \mathrm{Si}_{2} \mathrm{O}_{5}(\mathrm{OH})_{4}+4 \mathrm{H}_{4} \mathrm{SiO}_{4} \\
\underset{\text { anorthite }}{\mathrm{CaAl}_{2} \mathrm{Si}_{3} \mathrm{O}_{8}+9 \mathrm{H}_{2} \mathrm{O}+2 \mathrm{H}^{+}} \rightarrow \mathrm{Ca}^{2+}+\mathrm{Al}_{2} \mathrm{Si}_{2} \mathrm{O}_{5}(\mathrm{OH})_{4}+4 \mathrm{H}_{4} \mathrm{SiO}_{4}
\end{gathered}
$$

The hyper salinity of some groundwaters in the investigated aquifer might be attributed to a different factor other than the typical known geochemical processes. The high temperature of some groundwater samples (Table 2) may suggest that the aquifer is subjected to an internal or external source of heat which might led to the concentration of salinity over time. A deep heating in a naturally occurring hydrothermal system might occur to groundwater due to the presence of a nearby magma chamber or high radionuclide content within an aquifer (Figure 9 \& Figure 10). The significant content of the natural radionuclides within the investigated aquifer (Table 2) supports that the natural radioactivity is the source of heat within the aquifer. Based on the bivariate diagram of $\mathrm{Na} / \mathrm{Cl}$ versus chloride relationship (Figure 11), the high-salinity samples ( $\mathrm{Na}-\mathrm{Cl}$ type) plot on the evaporation trend, which might support the proposed hypothesis.

Table 1. Result of the Phreeqc geochemical model along the flow path RAK-03 to RAK-02.

\begin{tabular}{ccc}
\hline Phase & Mole transfers & Chemical Formula \\
\hline Halite & $2.001 \times 10^{+00}$ & $\mathrm{NaCl}$ \\
Kaolinite & $-5.067 \times 10^{-03}$ & $\mathrm{Al}_{2} \mathrm{Si}_{2} \mathrm{O}_{5}(\mathrm{OH})_{4}$ \\
Dolomite & $-1.414 \times 10^{-03}$ & $\mathrm{CaMg}_{\left(\mathrm{CO}_{3}\right)_{2}}$ \\
Gypsum & $4.692 \times 10^{+00}$ & $\mathrm{CaSO}_{4}: 2 \mathrm{H}_{2} \mathrm{O}$ \\
Anhydrite & $-4.690 \times 10^{+00}$ & $\mathrm{CaSO}_{4}$ \\
Mackinawite & $-2.592 \times 10^{-07}$ & $\mathrm{FeS}$ \\
Illite & $-5.357 \times 10^{-04}$ & $\mathrm{~K}_{0.6} \mathrm{Mg}_{0.25} \mathrm{Al}_{2} \cdot 3 \mathrm{Si}_{3} \cdot 5 \mathrm{O}_{10}(\mathrm{OH})_{2}$ \\
K-mica & $3.794 \times 10^{-03}$ & $\mathrm{KAl}_{3} \mathrm{Si}_{3} \mathrm{O}_{10}(\mathrm{OH})_{2}$ \\
\hline
\end{tabular}

Table 2. Concentrations of the radionuclides and the environmental isotopes for some groundwater samples of Waia-Biyadh Aquifer (MEWA, 2017a).

\begin{tabular}{cccccccccccccccc}
\hline Well & Aqu. & pH & TDS & $\mathrm{O}_{2}$ & $\mathrm{Eh}$ & $\mathrm{T} \cdot \mathrm{C}$ & $\begin{array}{c}\mathrm{K} \\
(\mathrm{mg} / \mathrm{l})\end{array}$ & $\begin{array}{c}\mathrm{gr} . \mathrm{A} \\
(\mathrm{mBq} / \ell)\end{array}$ & $\begin{array}{c}\mathrm{gr} \cdot \boldsymbol{\beta} \\
(\mathrm{mBq} / \ell)\end{array}$ & $\begin{array}{c}{ }^{234} \mathrm{U} \\
(\mathrm{mBq} / \ell)\end{array}$ & $\begin{array}{c}{ }^{238} \mathrm{U} \\
(\mathrm{mBq} / \ell)\end{array}$ & $\begin{array}{c}{ }^{226} \mathrm{Ra} \\
(\mathrm{mBq} / \ell)\end{array}$ & $\begin{array}{c}{ }^{228} \mathrm{Ra} \\
(\mathrm{mBq} / \ell)\end{array}$ & $\begin{array}{c}\delta^{2} \mathrm{H} \\
\% 0\end{array}$ & $\begin{array}{c}\delta^{18} \mathrm{O} \\
\% 0\end{array}$ \\
\hline RAK-01E & $\mathrm{w}$ & 6.20 & 68,500 & n.d & n.d & 80.6 & 497 & $\mathbf{5 2 0 8}$ & 7342 & 1 & $<1$ & 5200 & 2200 & -20.8 & 0.52 \\
RAK-03E-WB & $\mathrm{w}$ & 6.95 & 3430 & n.d & n.d & 94.8 & 56.6 & 434 & 2577 & 2 & 1 & 430 & 750 & -41.4 & -6.66 \\
RAK-04E & $\mathrm{w}$ & 6.60 & 1161 & 0.25 & n.d & 47.4 & 12.8 & n.d. & n.d. & 26 & 25 & b.d.l. & b.d.l. & -47.2 & -6.4 \\
RAK-02E & W-B-S & 5.68 & 232,000 & n.d & n.d & 79.0 & 567.0 & 1929 & $\mathbf{1 7 , 3 5 6}$ & 5 & 3 & 1600 & 140 & -20.8 & 0.52 \\
\hline
\end{tabular}




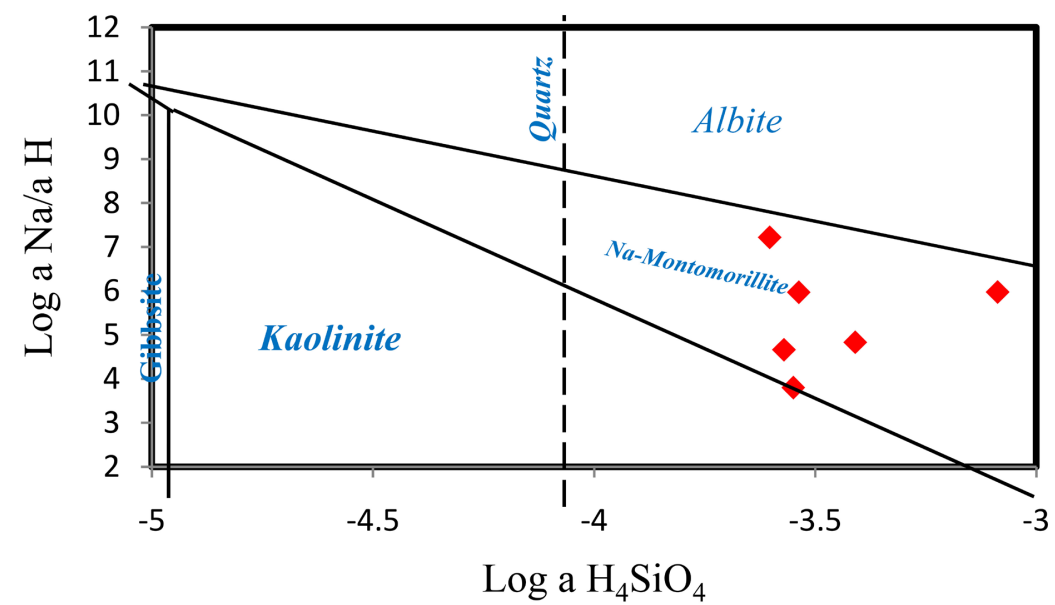

(a)

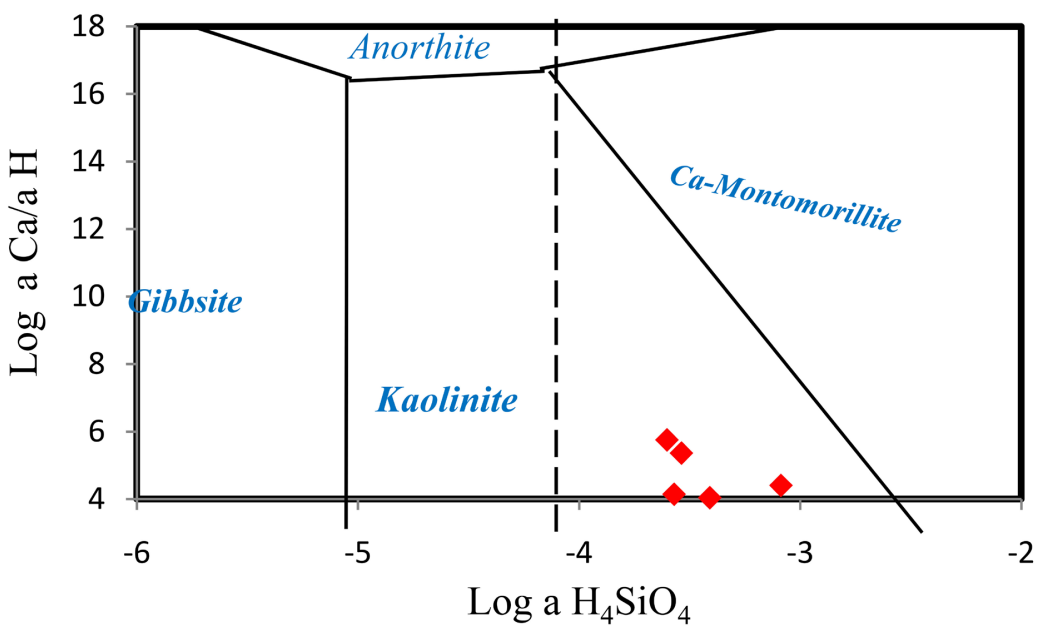

(b)

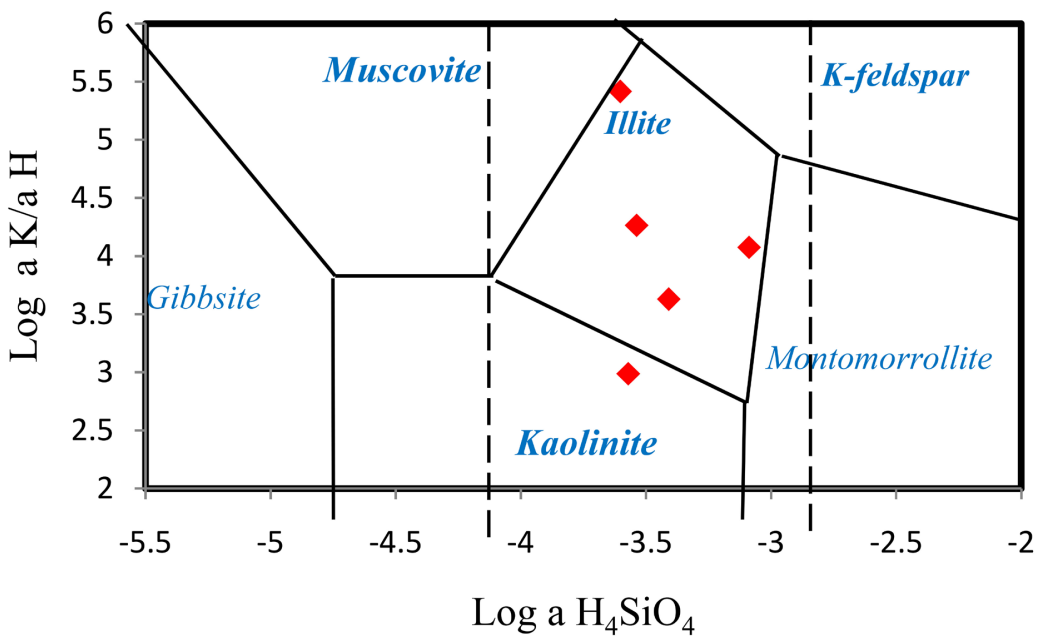

(c)

Figure 8. Stability field of (a) Ca-Al silicate phases, (b) $\mathrm{Na}-\mathrm{Al}$ silicate phases, and (c) $\mathrm{K}-\mathrm{Al}$ silicate phases relative to some selected groundwater samples. Most of the groundwater samples appear to lie at/or close to equilibrium with montmorillonite, kaolinite and illite. 


\section{acid sulfate springs}

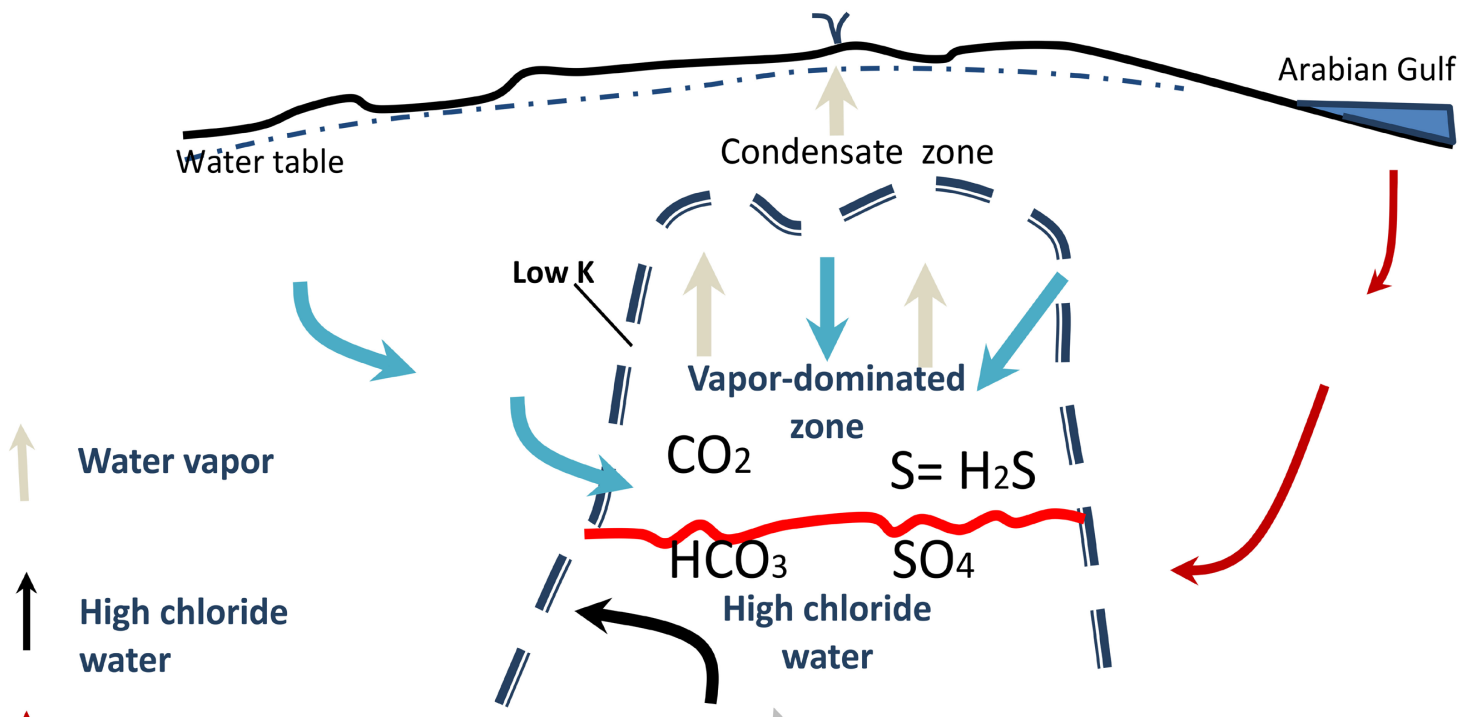

Sea water

High radionuclide content

Figure 9. A vapor-dominant condition might cause salinity to concentrate in groundwater (modified after Ingebritsen \& Sorey, 1988).

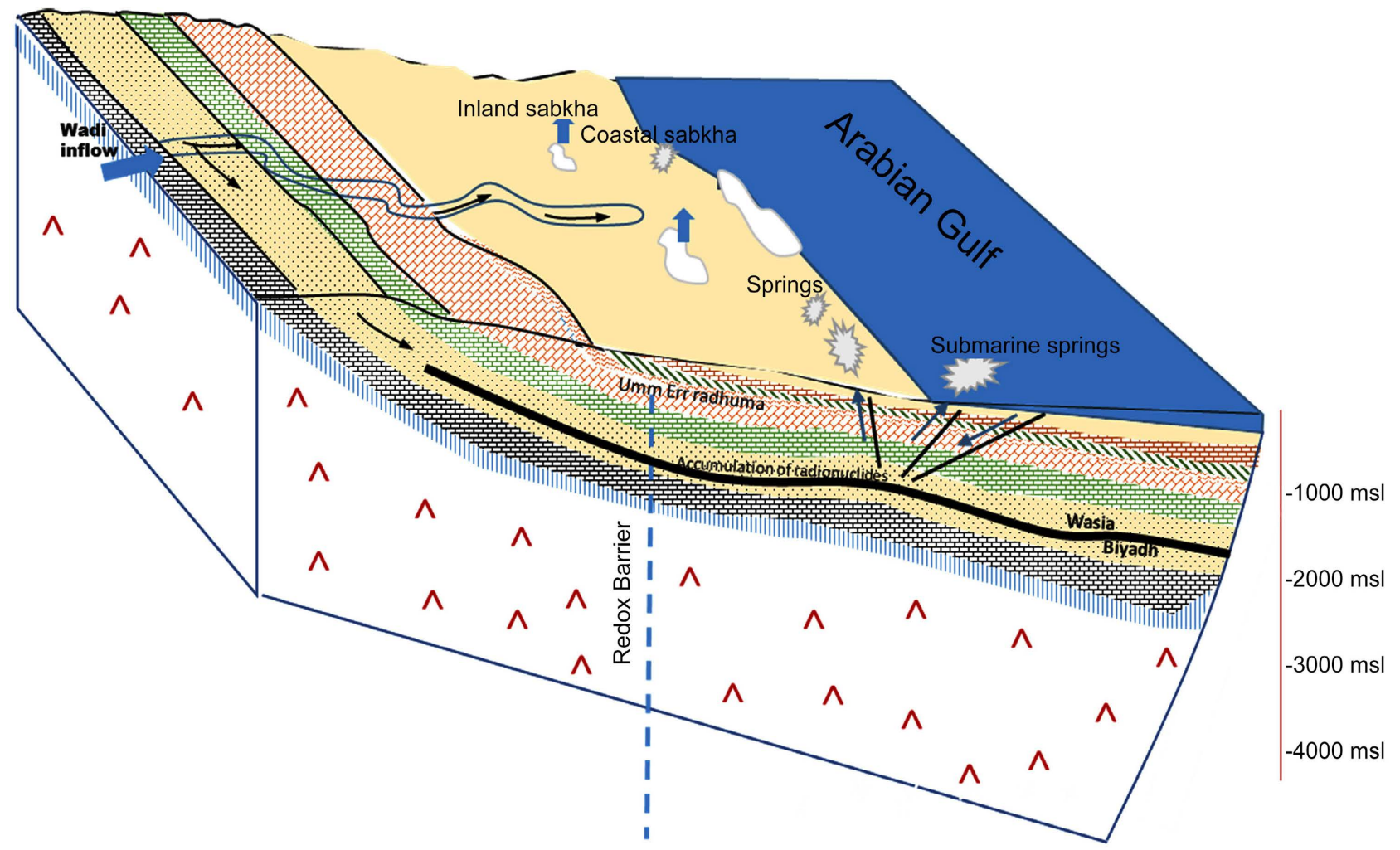

Figure 10. A Schematic diagram showing the effect of the accumulation of the radionuclides in Wasia-Biyad aquifer. 


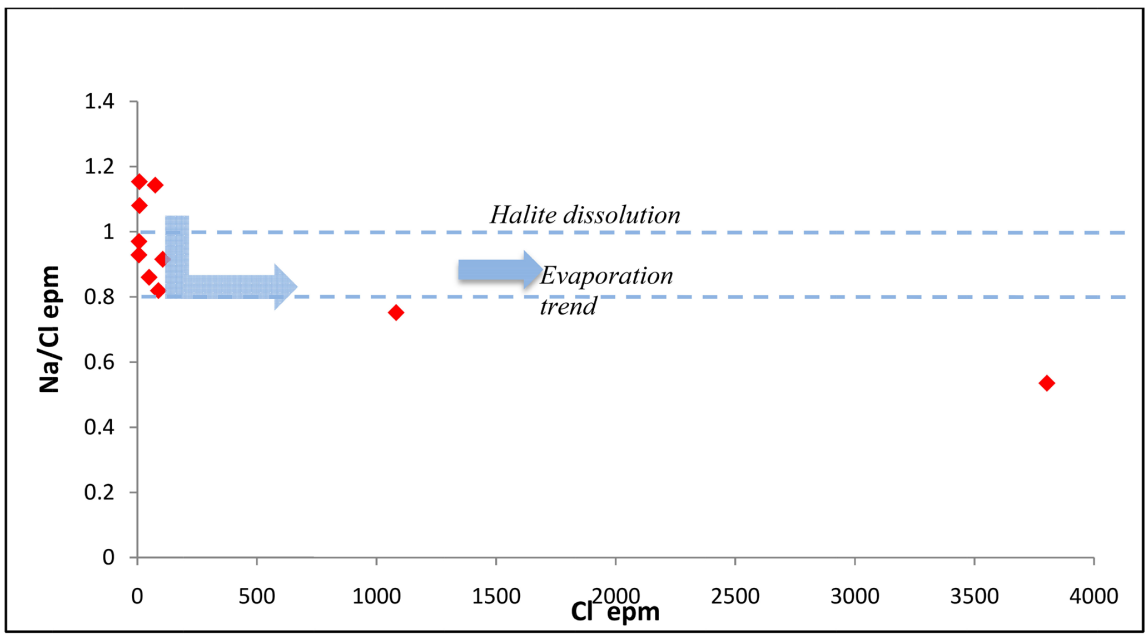

Figure $11 . \mathrm{Na}^{+} / \mathrm{Cl}^{-}$vs. $\mathrm{Cl}^{-}$relationship, indicating the sources of sodium ions.

\section{Conclusion}

The groundwater samples in the western parts of the aquifer showed a broad range of TDS concentration, ranging between a few hundred to $3000 \mathrm{mg} / \ell$, belonging to a $\mathrm{Ca}-\mathrm{HCO}_{3}$ water type. A gradual increase in the TDS concentrations was observed in groundwater along the flow path. However, some samples showed hyper salinity with a TDS concentration of up to $230,000 \mathrm{mg} / \ell$ and a $\mathrm{Na}-\mathrm{Cl}$ water type towards the eastern parts of the study area. According to the hydrochemical and the natural radioactivity data, the presence of a naturally occurring hydrothermal system within the aquifer was considered the source of internal heat that led to heating up the groundwater and hence salinity concentrated over time. However, the geochemical reactions contributed salinity to groundwater. The geochemical reactions in the eastern part of the aquifer included the precipitation of pyrite, dolomite, clay, and the incongruent dissolution of plagioclase.

\section{Conflicts of Interest}

The authors declare no conflicts of interest regarding the publication of this paper.

\section{References}

Al-Mashaikhi, K. S. (2011). Evaluation of Groundwater Recharge in Najd Aquifers Using Hydraulics, Hydrochemical and Isotope Evidences. Dissertation, Helmholtz Centre for Environmental Research-UFZ and Friedrich-Schiller-University Jena.

Avrahamov, N., Antler, G., Yechieli, Y., Gavrieli, I., Joye, S. B., Saxton, M., Turchyn, A. V., \& Sivan, O. (2014). Anaerobic Oxidation of Methane by Sulfate in Hypersaline Groundwater of the Dead Sea Aquifer. Geobiology, 12, 511-528. https://doi.org/10.1111/gbi.12095

Berry, F. A. (1969). Relative Factors Influencing Membrane Filtration Effects in Geologic Environments. Chemical Geology, 4, 295-301.

https://doi.org/10.1016/0009-2541(69)90051-5

BRGM (Bureau de Recherches Géologiques et Minières) (1976). Hydrogeological Inves- 
tigations of the Al Wasia Aquifer in the Eastern Province of Saudi Arabia, Regional Study, Final Report, Appendix 3-Isotopic Analyses. Unpublished Report, Ministry of Agriculture and Water.

De Sitter, L. (1947). Diagenesis of Oil-Field Brines. AAPG Bulletin, 31, 2030-2040. https://doi.org/10.1306/3D933A7C-16B1-11D7-8645000102C1865D

Elango, L., \& Kannan, R. (2007). Rock-Water Interaction and Its Control on Chemical Composition of Groundwater. Developments in Environmental Science, 5, 229-243. https://doi.org/10.1016/S1474-8177(07)05011-5

Engelen, J., Gualbert, H. P., Essink, O., Kooi, H., \& Marc, F. P. (2018). On the Origins of Hypersaline Groundwater in the Nile Delta Aquifer. Journal of Hydrology, 560, 301-317. https://doi.org/10.1016/j.jhydrol.2018.03.029

Freeze, R. A., \& Cherry, J. A. (1979). Groundwater (604 p). Prentice-Hall.

Gaillardet, J., Dupre, B., Louvat, P., \& Allegre, C. J. (1999). Global Silicate Weathering and $\mathrm{CO}_{2}$ Consumption Rates Deduced from the Chemistry of Large Rivers. Chemical Geology 159, 3-30. https://doi.org/10.1016/S0009-2541(99)00031-5

Ingebritsen, S. E., \& Sorey, M. L. (1988). Vapor-Dominated Zones within Hydrothermal Systems: Evolution and Natural State. Journal of Geophysical Research, 93, 635-655.

Kalbus, E., Oswald, S., Wang, W., Kolditz, O., Engelhardt, I., Al-Saud, M. I., \& Rausch, R. (2011). Large-Scale Modeling of the Groundwater on the Arabian Platform. International Journal of Water Resources and Arid Environments, 1, 38-47.

MEWA (2017a). Environmental Isotopes (Vol. 10). Detailed Groundwater Resources Studies in the Rub' Al Khali Desert. Internal Report, Ministry of Environment Water and Agriculture, MEWA.

MEWA (2017b). Geology (Vol. 1). Detailed Groundwater Resources Studies in the Rub' Al Khali Desert. Internal Report, Ministry of Environment Water and Agriculture, MEWA.

MEWA (2017c). Groundwater Quality-Hydrochemistry (Vol. 9). Detailed Groundwater Resources Studies in the Rub' Al Khali Desert, Internal Report, Ministry of Environment Water and Agriculture, MEWA.

MEWA (2017d). Hydrogeology (Vol. 14). Detailed Groundwater Resources Studies in the Rub’ Al Khali Desert, Internal Report, Ministry of Environment Water and Agriculture, MEWA.

MOWE (2013a). Environmental Isotopes (Vol. 12). Detailed Water Resources Studies of Wasia-Biyadh and Aruma Aquifers, Ministry of Water and Electricity, MOWE.

MOWE (2013b). Groundwater Quality-Hydrochemistry (Vol. 11, 207 p). Detailed Water Resources Studies of Wasia-Biyadh and Aruma Aquifers, Internal Report, Ministry of Water and Electricity, MOWE.

MOWE (2013c). Hydrogeology (Vol. 15, 90 p). Detailed Water Resources Studies of Wasia-Biyadh and Aruma Aquifers, Internal Report, Ministry of Water and Electricity, MOWE.

Sabarathinam, C., Harish, B., \& Asim, A. (2020). Tracing the Evolution of Acidic Hypersaline Coastal Groundwater in Kuwait. Arabian Journal of Geosciences, 13, Article No. 1146. https://doi.org/10.1007/s12517-020-06116-w

Stuyfzand, P. J., \& Stuurman, R. J. (1994). Recognition and Genesis of Various Brackish to Hypersaline Groundwaters in the Netherlands. In G. Barrocu, Ed., Proceedings of 13th Salt Water Intrusion Meeting (pp. 125-136). Cagliari: Università de glistudi di Cagliari. 
White, D. E. (1965). Saline Waters of Sedimentary Rocks. In A. Young, \& J. E. Galley (Eds.), Fluids in Subsurface Environments (Vol. 4, pp. 342-366). American Association of Petroleum Geologists, MEM. 